\title{
Ecosystem Carbon Storage and Partitioning in Chato Afromontane Forest: Its Climate Change Mitigation and Economic Potential
}

\author{
Birhanu Iticha
}

Soil Resource and Watershed Management Department, Wollega University, P. O. Box 395, Shambu, Ethiopia

\begin{abstract}
Forests trap carbon dioxide $\left(\mathrm{CO}_{2}\right)$ from the atmosphere, store in the form of carbon $(C)$ and regulate climate change. In this study, $C$ storage and climate change mitigation potential of Chato Afromontane forest was assessed from measurement of the major pools including the aboveground biomass, belowground biomass, dead tree biomass, plant litter and soil organic carbon (SOC). The result showed that biomass accumulation was comparatively larger for natural forest than plantations due to maturity, intactness and species diversity. The total $C$ storage capacity of the forest ranged from $107.12 \mathrm{Mg} \mathrm{ha}^{-1}$ for acacia plantation to $453.21 \mathrm{Mg} \mathrm{ha}^{-1}$ for the intact natural forest. The mean $C$ storage capacity by major pools ranged from $1.36 \mathrm{Mg} \mathrm{ha}^{-1}$ for the dead tree C to $157.95 \mathrm{Mg}$ $\mathrm{ha}^{-1}$ for the aboveground $\mathrm{C}$ pool. The forest ecosystem accumulated a total of nearly $6371.30 \mathrm{Gg} C$ in the vegetation plus soil to a depth of $60 \mathrm{~cm}$. The large volume of annually trapped $C$ by the vast channels of Chato forest makes it the most significant regulator of global climate change. Conservation of the sacred forest will have an imperative implication to the net positive $C$ addition ensuring its viability for the international $C$ market.

Keywords - Forest, Chato forest, Afromontane forest, carbon storage, carbon sequestration rate, climate change, carbon credit.
\end{abstract}

\section{INTRODUCTION}

Forests are land use systems with high tree population and store large quantities of C (Lal 2005). Forest ecosystem store more than $80 \%$ of all terrestrial aboveground $\mathrm{C}$ and more than $70 \%$ of all soil C (Batjes 1996). According to Batjes (1996) the pedologic and biotic pools together are called the terrestrial $\mathrm{C}$ pools, and they are estimated at 2860 $\mathrm{Pg}$ or $2860 \mathrm{Gt}(1 \mathrm{Gt}=1 \mathrm{Pg}=1$ billion metric tons $)$. Terrestrial $\mathrm{C}$ is the $\mathrm{C}$ stored in terrestrial ecosystems as living or dead plant biomass (aboveground and belowground) and in the soil along with usually negligible quantities as animal biomass. The main $\mathrm{C}$ pools in tropical forest ecosystem are the living biomass of tree and understory vegetation, dead mass of litter and woody debris, and soil organic matter. The vegetation of tropical forests is a large and globally significant storage of $\mathrm{C}$ because tropical forests contain more $\mathrm{C}$ per unit area than any other land cover (Hairiah et al. 2011). The forest resources of Ethiopia store 2.76 billion tons of $\mathrm{C}$ (about 10 billion $\mathrm{Mg}$ of $\mathrm{CO}_{2}$ ) in the aboveground biomass (Yitebitu Moges et al. 2010). Forests can be both sources of atmospheric $\mathrm{CO}_{2}$ when disturbed by natural or human causes, and sinks, when vegetation and soil $\mathrm{C}$ accumulate after disturbance, depending on land management thus potentially accelerating or mitigating climate change (Lal 2004).

The REDD' strategy, namely "reducing emissions from deforestation and forest degradation, and foster conservation, sustainable management of forests and enhancement of forest $\mathrm{C}$ stocks (through afforestation and regeneration) are keys to ensure net positive $C$ addition that would then become a credit that could be sold in an international $\mathrm{C}$ market. However, the potential of $\mathrm{C}$ financing through REDD+ on forest $\mathrm{C}$ sequestration in tropical forests has not been systematically studied. The general allometric models developed by Pearson et al. (2005) and Chave et al. (2005) have been widely used, notably in the context of REDD+, and were recommended by the IPCC guidelines (IPCC 2006) for estimating C stocks in tropical forests. The general model developed by Chave et al. (2005) including tree height provided best biomass estimates specifically for moist tropical forests and reduce uncertainties as compared to other generic models (Ervan et al. 2013).

Afromontane forests are among the most species-rich ecosystems on earth (Schmitt et al. 2010). The study was conducted in Chato Afromontane forest ecosystem, one of the largest sacred forests in Ethiopia comprising of untouched natural forest and tree plantations. Although not studied so far, the wide range of tree plantations and high endemic plant species in Chato forest makes it the most 
powerful $\mathrm{C}$ sinks in the tropics. Therefore, the study was designed mainly to estimate $\mathrm{C}$ storage capacity and $\mathrm{CO}_{2} \mathrm{e}$ sink of the forest ecosystem so as to unveil the climate change mitigation and economic prospective of the forest.

\section{MATERIALS AND METHODS}

\subsection{The study site}

Chato forest is situated between 9.62898256 to $9.810748292 \mathrm{~N}$ and 36.90419252 to $37.06710714 \mathrm{E}$ (Fig. 1) in the western parts of Ethiopia with an elevation ranging from 1700 to $2350 \mathrm{~m}$ asl. It is found at about $30 \mathrm{~km}$ northwest of Shambu, the capital city of Horo Guduru Wollega Zone, Oromia Region. The forest was demarcated as National Forest Priority Areas (NFPA) and has been known by the name Chato-Sangi-Dangab forest in the country (EFAP 1994). The forest is classified under moist evergreen Afromontane forest consisting high diversity of endemic tree species and a variety of wildlife. Chato forest covers about 14,290.97 hectares (ha) of land comprising of species rich natural forest $(13670.06$ ha) and various tree plantations including 17 to 29 years old acacia spp. (6.05 ha), 18 to 31 years Cupressus lusitanica (434.21 ha), 25 to 31years old Juniperus procera (2.97 ha), 14 to 31 years old
Gravellia robusta $(3.43 \mathrm{ha})$ and 14 to 31 years old eucalyptus spp. (174.25 ha) such as Eucalyptus citrodora, Eucalyptus saligna, Eucalyptus comandulus. The area is characterized by having unimodal rainfall distribution with mean annual rainfall of $1566 \mathrm{~mm}$ and mean annual temperature of $16.7^{\circ} \mathrm{C}$.

\subsection{Forest stratification and sampling techniques}

Compartments or strata established during forest inventory by Horo Guduru Forest and Wildlife Enterprise, mainly based on forest stand type was used for biomass assessment. Besides, part of the forest that was not addressed during inventory by the Enterprise was stratified during the study. The area of each forest stand was tracked by using ground positioning system (GPS). In the stratum or forest stand, nested sample plots of $20 \mathrm{~m} \times 20 \mathrm{~m}, 2 \mathrm{~m} \times 2 \mathrm{~m}$ and $1 \mathrm{~m} \times 1$ $\mathrm{m}$ were randomly laid to measure the biomass of woody plants, herbaceous/saplings and litter biomasses, respectively. A total of 105 sample plots were taken for C stock inventory. Sample plots in the same stand, namely eucalyptus, acacia, Cupressus lusitanica, Juniperus procera, Gravellia robusta and natural forest were weighed to give average biomass and $\mathrm{C}$ stock for each stand type.

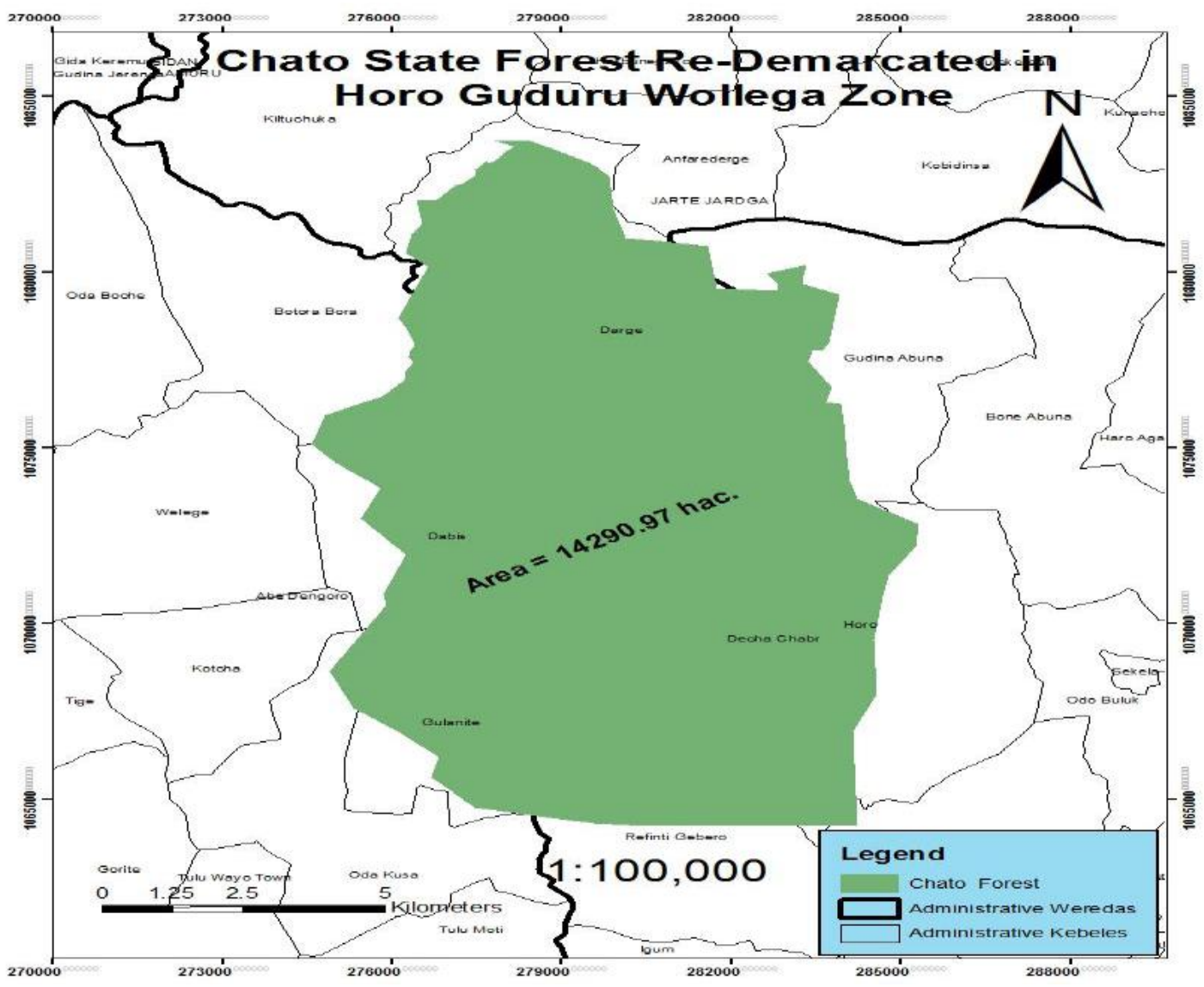

Fig. 1: Areal coverage and location map of Chato state forest 
2.3. Soil sampling and analysis

Carbon stock inventory for the soil was done for the upper $60 \mathrm{~cm}$ depth in the nested plot, by collecting samples from 0-30 and 30-60 cm layers at 20 locations. Following sample preparation, samples were analyzed based on the standard laboratory procedures. Bulk density was determined using core method (Blake and Hartge 1986) while SOC was determined using Walkley-Black oxidation method (Walkley and Black 1934).

\subsection{Estimation of biomass in different pools}

The major biomass components or pools assessed include aboveground live biomass, dead tree biomass, below ground biomass, and litter biomass.

\subsubsection{Aboveground live biomass (AGLB)}

In each $20 \mathrm{~m}$ x $20 \mathrm{~m}$ sampling plot, diameter at breast height $(\mathrm{DBH})$ and tree height $(\mathrm{H})$ were measured for every live tree using caliper and hypsometer, respectively. Then, the aboveground biomass of live trees with $\mathrm{DBH} \geq 5 \mathrm{~cm}$ was estimated by using general allometric equation recommended by Chave et al. (2005) for moist tropical forest stands as indicated hereunder:

$$
A G T B=0.0509 *\left(\rho D^{2} H\right)
$$

where $A G T B$ is aboveground tree biomass $(\mathrm{kg}), \rho$ is wood specific gravity $\left(\mathrm{g} \mathrm{cm}^{-3}\right), D$ is tree $\mathrm{DBH}(\mathrm{cm})$, and $H$ is tree height $(\mathrm{m})$. Besides, live grasses, shrubs, herbs, saplings, and some tree seedlings from natural regeneration with a DBH $<5$ cm (Pearson et al., 2005) were harvested in each 2 $\mathrm{m} \times 2 \mathrm{~m}$ subplot located in every corner and center of the main plot $\left(400 \mathrm{~m}^{2}\right)$ in the nest. In $4 \mathrm{~m}^{2}$ subplot, total fresh weight of harvested plant material was measured, from which $500 \mathrm{~g}$ sample size was taken to the laboratory, ovendried at $85{ }^{\circ} \mathrm{C}$ and reweighed to estimate the dry matter of aboveground grasses, shrubs, herbs and saplings biomass (AGHSB). Finally, aboveground live biomass was the sum of aboveground tree biomass and aboveground grasses, shrubs, herbs, and saplings biomass.

\subsubsection{Belowground biomass (BGB)}

Belowground biomass was estimated from aboveground biomass on the basis of root to shoot ratio of $(0.24: 1)$ recommended by Cairns et al. (1997) for moist tropical forests (woody and non-woody).

\subsubsection{Dead tree biomass (DTB)}

The dead tree biomass was estimated for standing and downed dead trees following (CSEMF 2011) equations.
Standing dead tree biomass (SDTB) was estimated by classifying the dead tree into three classes. The first class works for standing dead tree with small and large braches and twigs but without leaves. In this case, general allometric equation was used to estimate biomass and $2 \%$ was deducted due to absence of leaves. The second class works for standing dead tree with no twigs but only some large branches. In this case:

$$
V B=\left(\frac{\pi^{*} H}{12}\right)\left(D_{b}^{2}+\left(D_{b}+D_{t}\right)+D_{t}^{2}\right)
$$

The third class works for standing dead tree with bole (trunk) only. In this case:

$V B=\frac{\left(D_{b}^{2 *} D_{t}^{2}\right)+H}{8}$

where VB is volume biomass, $H$ is height of stem, $D_{b}$ and $D_{t}$ are diameter at base of the tree and top of the stump, respectively. Downed dead tree biomass (DDTB) was determined from volume estimate as:

$V B=0.25 \pi\left(\frac{D_{b}+D_{t}}{2 * 100}\right)^{2} * H$

where VB is volume of dead wood $\left(\mathrm{m}^{3}\right), D_{b}$ is diameter of the base of the dead wood $(\mathrm{cm}), D_{t}$ is diameter of the tip of the dead wood $(\mathrm{cm}), \mathrm{H}$ is length of the dead wood $(\mathrm{m})$.

For standing dead trees of case 2 and 3 and downed dead trees, sample wood density was estimated by floating method (by cutting a disk of wood) and drying until a constant mass was obtained. Hence, wood density was estimated by dividing dry weight of the disk by volume of the disk. Subsequently, standing dead tree biomass of class 2 and 3 and downed dead tree biomass was estimated by multiplying volume biomass by their wood densities. Biomass of standing dead tree under each case was summed up to give total SDTB. Finally, SDTB and DDTB were summed to provide DTB.

\subsubsection{Litter biomass (LB)}

The dry matter of litter and finer plant debris was collected from $1 \mathrm{~m} \mathrm{x} 1 \mathrm{~m}$ plot in every four corners and center of the main $400 \mathrm{~m}^{2}$ plot in the nest. In the $1 \mathrm{~m}^{2}$ plot, litter was collected and total fresh weight was recorded, from which $250 \mathrm{~g}$ sample size was taken to the laboratory, oven-dried at $85{ }^{\circ} \mathrm{C}$ and reweighed to estimate the dry matter.

\subsection{Calculation of carbon stock from biomass}

The amount of $\mathrm{C}$ stored in each pool $(\mathrm{kg})$ was determined by multiplying the biomass of each pool $(\mathrm{kg})$ to 0.50 
(Payton and Waever 2011) as follows:

$$
C_{X}=\text { Biomass } * 0.5
$$

\subsection{Calculation of carbon storage capacity}

Then, $\mathrm{C}$ storage capacity $\left(\mathrm{Mg} \mathrm{ha}{ }^{-1}\right)$ was calculated by dividing the $C_{x}$ stored in each pool and each subplot $(\mathrm{kg})$ by area of the subplot $\left(\mathrm{m}^{2}\right)$ and multiplying with 10 as follows:

$$
\text { C storagecapacity }=\left(\frac{C x}{A}\right) * 10
$$

where $C$ storage capacity was estimated for each types of pools (i.e. AGB, BGB, DTB, and LB) expressed as $\mathrm{Mg} \mathrm{ha}^{-1}$ and 10 is a conversion factor from $\mathrm{kg} \mathrm{m}^{-2}$ to $\mathrm{Mg} \mathrm{ha}^{-1}$.

\subsection{Estimation of soil organic carbon (SOC)}

The SOC $\left(\mathrm{Mg} \mathrm{ha}^{-1}\right)$ to specific soil depth was estimated as: $S O C=O C * \rho b * d * C F U$

where $O C$ is $\mathrm{mg} \mathrm{g}^{-1} \mathrm{C}$ concentration, $d$ is soil thickness or depth i.e. $0-30$ and $30-60 \mathrm{~cm}, \rho_{b}$ is bulk density of the soil $\left(\mathrm{g} \mathrm{cm}^{-3}\right)$ and $C F U$ is correction factor for units $\left(=10^{-1}\right)$.

\subsection{Quantifying total carbon stock (TCS)}

The total $\mathrm{C}$ stock in the nested plot expressed in $\left(\mathrm{Mg} \mathrm{ha}^{-1}\right)$ was calculated by adding $\mathrm{C}$ stored in all pools in each subplot in the nest according to the equation:

$$
C_{\text {plot }}=C_{A G L B}+C_{B G B}+C_{D T B}+C_{L B}+S O C
$$

where $C_{A G L B}, C_{B G B}, C_{D T B}, C_{L B}$, and $S O C$ were $C$ stored in the aboveground live biomass, belowground biomass, dead tree biomass, litter biomass, and in the soil in the subplots expressed in $\left(\mathrm{Mg} \mathrm{ha}^{-1}\right)$, respectively. The amount of $\mathrm{C}$ stored in each types of forest stand $(\mathrm{Mg})$ was calculated as follows:

$$
C_{s t}=\left(\frac{\sum C_{p l o t}}{n_{p l o t}}\right) * A_{s t}
$$

where $C_{p l o t}$ is the total $\mathrm{C}$ stored in each plots expressed in $\left(\mathrm{Mg} \mathrm{ha}^{-1}\right), n_{\text {plot }}$ is the number of sample plots in the stand, $A_{s t}$ is area of each stand (ha). The total C stock in the whole forest was calculated as follows:

$$
C_{T}=\sum C_{s t}
$$

where $C_{T}$ is total $\mathrm{C}$ stock $(\mathrm{Mg})$ and $C_{s t}$ is the total $\mathrm{C}$ stock of each forest stand $(\mathrm{Mg})$.

\subsection{Estimation of equivalent $\mathrm{CO}_{2}$ sink}

Finally, as $1 \mathrm{Mg}$ of soil $\mathrm{C}=3.67 \mathrm{Mg}$ of $\mathrm{CO}_{2}$ sequestered (Craig et al., 2010), the equivalent $\mathrm{CO}_{2}$ sink (Mg) in Chato forest was estimated based on the total $\mathrm{C}$ stock as follows:

$$
\mathrm{CO}_{2} e=3.67 * C_{T}
$$

Values in $\mathrm{Gg}$ can be obtained by dividing $\mathrm{Mg}$ of $\mathrm{OC}$ or $\mathrm{CO}_{2}$ by 1000 .

\subsection{Statistical data analysis}

Descriptive statistics was used to summarize mean and coefficient of variation of measured parameters. Generalized biomass models developed for moist tropical forests were used to determine carbon stock of forests. Mean separation was carried out using least significant difference (LSD) at $\mathrm{p}<0.05$.

\section{RESULTS AND DISCUSSION}

3.1. Impact of stand type and biomass component on biomass accumulation

Biomass accumulation in the forest ecosystem is usually influenced by kind of forest, type of pool, tree size class and density, species composition, forest age, and level of protection, all of which determine the $\mathrm{C}$ storage level of the forest. The study result shows that Chato natural forest had accumulated large volume of biomass than plantation forest for similar pools (Table 1). Total biomass accumulation, the sum of biomass stored in all components, was highest for the natural forest followed by plantations including eucalyptus species, Cupressus lusitanica, Juniperus procera, Gravellia robusta, and lowest for acacia species. Larger biomass in natural forest might be attributed to maturity, species diversity and good understory cover.

The study result shows that the average biomass stored ( $\mathrm{Mg}$ $\mathrm{ha}^{-1}$ ) in different biomass pools decreased in order AGB > $\mathrm{BGB}>\mathrm{LB}>\mathrm{DTB}$ for all types of forest stands. The quantity of biomass accumulated in the aboveground biomass pool was significantly different from other pools at $(\mathrm{p}<0.05)$ indicating more biomass was accumulated in the aboveground pool. The mean biomass accumulated in Chato forest by biomass components ranged from $2.73 \mathrm{Mg}$ $\mathrm{ha}^{-1}$ in the dead tree to $315.90 \mathrm{Mg} \mathrm{ha}^{-1}$ in the aboveground biomass pools. Canopy cover, basal area, and height of trees might be attributed to the larger proportion of biomass in the aboveground biomass pool. The average value of the aboveground biomass for natural forest in the present study (603.72 $\mathrm{Mg} \mathrm{ha}^{-1}$ ) was higher than the findings of Brown and Lugo (1982) and Abel Girma et al. (2014) who reported a range of 225 to $446 \mathrm{Mg} \mathrm{ha}^{-1}$ for the tropical rain forests in Malaysia and a mean value of $475.51 \mathrm{Mg} \mathrm{ha}^{-1}$ for woody plants of Mount Zequalla Monastery in Ethiopia, respectively. However, the present result is almost similar 
with the aboveground biomass values of $607.7 \mathrm{Mg} \mathrm{ha}^{-1}$ reported for tropical wet evergreen forest of western India (Rai 1981) and less than 994.16 $\mathrm{Mg} \mathrm{ha}^{-1}$ reported for forest in the lowland area of Simien mountains national park of Ethiopia (Tibebu Yelemfrhat et al. 2014). The average aboveground biomass for plantation forest in the present study (258.34 $\mathrm{Mg} \mathrm{ha}^{-1}$ ) was less than the aboveground biomass of plantation forest in the humid tropics in northeast India (406.4 $\mathrm{Mg} \mathrm{ha}^{-1}$ ) (Ratul et al. 2009) but greater than $223.6 \mathrm{Mg} \mathrm{ha}^{-1}$ reported by Wondrade et al. (2015). Nearly $78.99 \%$ of total biomass in the natural forest was allocated in the aboveground biomass (Table 2) while the remaining pools were accumulated only $21.01 \%$ biomass. In all forest stands, the smallest biomass was recorded in the dead tree/wood compared with other pools. Low tree mortality and decomposition of deed woods might be the causes for low dead tree biomass. The aboveground shrubs and saplings biomass was highly variable with stand type than other pools as depicted by larger coefficient of variation $(76.73 \%)$ (Table 1$)$. This could be due to differences in suitability of various forest stands for the understory growth and it was more vigorous in the natural forest than plantations.

Table.1: Average biomass accumulation in the different forest stands and biomass components

\begin{tabular}{|c|c|c|c|c|c|c|}
\hline \multirow[b]{2}{*}{ Forest category } & \multicolumn{5}{|c|}{ Biomass storage $\left(\mathrm{Mg} \mathrm{ha}^{-1}\right)$ in different components } & \multirow[b]{2}{*}{ Total } \\
\hline & AGTB & AGHSB & BGB & DTB & LB & \\
\hline Eucalyptus spp. & 396.34 & 13.80 & 98.43 & 3.18 & 6.50 & 518.25 \\
\hline Acacia spp. & 90.35 & 9.13 & 23.87 & 0.67 & 2.80 & 126.82 \\
\hline Cupressus lusitanica & 353.83 & 6.45 & 86.47 & 3.53 & 4.20 & 454.48 \\
\hline Juniperus procera & 233.69 & 8.05 & 58.02 & 3.14 & 3.50 & 306.40 \\
\hline Gravellia robusta & 175.73 & 4.33 & 43.21 & 0.31 & 2.30 & 225.88 \\
\hline Natural forest & 574.54 & 29.18 & 144.89 & 5.52 & 10.20 & 764.33 \\
\hline Mean & $304.08^{\mathrm{b}}$ & $11.82^{\mathrm{a}}$ & $75.82^{\mathrm{a}}$ & $2.73^{\mathrm{a}}$ & $4.92^{\mathrm{a}}$ & \\
\hline $\mathrm{CV}(\%)$ & 57.20 & 76.73 & 57.42 & 71.50 & 60.61 & \\
\hline
\end{tabular}

AGTB: aboveground tree biomass; AGHSB: aboveground grasses, herbaceous, shrubs, and saplings biomass; BGB: belowground biomass; DTB: dead tree biomass; LB: litter biomass; and CV: coefficient of variation. AGB = AGTB + AGHSB. Means within rows followed by different letters are significantly different at $(p<0.05)$.

Table.2: Percent biomass allocation in different pools for various forest stands

\begin{tabular}{llllc}
\hline Type of forest & \multicolumn{4}{c}{ Biomass allocation (\%) } \\
\cline { 2 - 5 } & AGB & BGB & DTB & LB \\
\hline Eucalyptus spp. & 79.14 & 18.99 & 0.61 & 1.25 \\
Acacia spp. & 78.44 & 18.82 & 0.53 & 2.21 \\
Cupressus lustanica & 79.27 & 19.03 & 0.78 & 0.92 \\
Juniperus procera & 78.90 & 18.94 & 1.02 & 1.14 \\
Gravellia robusta & 79.71 & 19.13 & 0.14 & 1.02 \\
Natural forest & 78.99 & 18.96 & 0.72 & 1.33 \\
\hline
\end{tabular}

Previous research indicated that matured forests do not add up significant quantity of biomass because there is no net addition to the aboveground biomass density (Ratul et al. 2009). Instead, they are important for regeneration and sustaining a large volume of an already accumulated biomass and biodiversity. Newly established plantations are; however, add significant quantities of biomass to the ecosystem. The contribution of younger forests to the total biomass varied with the rate of growth suggesting fast growing trees have an increasing biomass storage rate than slow growing ones until the time of maturity.

\subsection{Carbon storage capacity of different forest stands and pools}

The total C storage capacity of different stands decreased in the following order: natural forest > eucalyptus species > Cupressus lusitanica > Juniperus procera > Gravellia robusta > acacia species (Table 3). The mean $\mathrm{C}$ storage 
capacity of the natural forest in the entire pools was 453.21 $\mathrm{Mg} \mathrm{ha}^{-1}$ whereas that of plantations (viz. eucalyptus species, Cupressus lusitanica, Juniperus procera, Gravellia robusta, and acacia species) was $208.08 \mathrm{Mg} \mathrm{ha}^{-1}$. Species richness, full ceiling canopy and several layers of understory might have contributed to the larger $\mathrm{C}$ storage potential of the natural forest. The average $\mathrm{C}$ storage capacity of Chato natural forest was greater than that of tropical rain forest of
Malaysia (223 $\left.\mathrm{Mg} \mathrm{ha}^{-1}\right)$, Indonesian forests $\left(161 \mathrm{Mg} \mathrm{ha}^{-1}\right)$ and Philippines forest $\left(258 \mathrm{Mg} \mathrm{ha}^{-1}\right)$ but smaller than the intact natural forests in south-eastern Australia (640 Mg ha$\left.{ }^{1}\right)$ reported by Brown and Lugo (1982), Murdiyarso and Wasrin (1995), Lasco et al. (2006) and Brendan et al. (2008), respectively. Combining $\mathrm{C}$ stored in the natural forest and plantations, the mean $\mathrm{C}$ storage capacity of Chato forest in the entire pools was $248.93 \mathrm{Mg} \mathrm{ha}^{-1}$.

Table.3: Average C storage potential in the different pools by major forest stands

\begin{tabular}{|c|c|c|c|c|c|c|}
\hline \multirow[b]{2}{*}{ Forest stand } & \multicolumn{5}{|c|}{ C storage capacity $\left(\mathrm{Mg} \mathrm{ha}^{-1}\right)$ in different pools } & \multirow[b]{2}{*}{ Total } \\
\hline & $\mathrm{AGC}$ & BGC & DTC & LC & SOC & \\
\hline Eucalyptus spp. & 205.07 & 49.22 & 1.59 & 3.25 & 41.70 & 300.83 \\
\hline Acacia spp. & 49.74 & 11.94 & 0.33 & 1.40 & 43.72 & 107.12 \\
\hline Cupressus lustanica & 180.14 & 43.23 & 1.77 & 2.10 & 53.16 & 280.40 \\
\hline Juniperus procera & 120.87 & 29.01 & 1.57 & 1.75 & 62.01 & 215.21 \\
\hline Gravellia robusta & 90.03 & 21.61 & 0.16 & 1.15 & 23.89 & 136.83 \\
\hline Natural forest & 301.86 & 72.45 & 2.76 & 5.10 & 71.04 & 453.21 \\
\hline & $157.95^{\mathrm{c}}$ & $37.91^{\mathrm{ab}}$ & $1.36^{\mathrm{a}}$ & $2.46^{\mathrm{a}}$ & $49.25^{\mathrm{b}}$ & \\
\hline & 57.42 & 57.42 & 71.50 & 60.61 & 33.78 & \\
\hline
\end{tabular}

Means within rows followed by different letters are significantly different at $(\mathrm{p}<0.05)$. AGC: aboveground carbon; BGC: belowground carbon; DTC: dead tree carbon; LC: litter carbon; and SOC: soil organic carbon.

The C storage capacity varies with type of pool. The AGC pool and SOC were significantly different from other pools and from each other at $(\mathrm{p}<0.05)$. The DTC and LC were also significantly different from AGC and SOC but not significantly different from each other at $(p<0.05)$. The study shows that the mean $\mathrm{C}$ stock of the major pools in each forest stand decreased as AGC $>\mathrm{SOC}>\mathrm{BGC}>\mathrm{LC}>$ DTC; implying more $\mathrm{C}$ allocation in the aboveground pool (Fig. 2). Nearly $63.45 \%$ of $\mathrm{C}$ was stored in the aboveground pool followed by $19.79,15.23,0.99$ and $0.55 \%$ in the soil, belowground, litter, and dead tree, respectively. This was in line with Zerihun Getu et al. (2012) report that tropical forests in their natural condition contain more aboveground $\mathrm{C}$ per unit area than any other land cover type. The average $\mathrm{C}$ stored in the aboveground pool for the natural forest was $301.86 \mathrm{Mg} \mathrm{ha}^{-1}$ while that of plantation forest was 129.17 $\mathrm{Mg} \mathrm{ha}^{-1}$. Combining the $\mathrm{C}$ sequestered in the natural forest and plantations, the mean aboveground $\mathrm{C}$ storage capacity of the Chato forest was $157.95 \mathrm{Mg} \mathrm{ha}^{-1}$. The average aboveground $\mathrm{C}$ for natural forest in the present study (301.86 $\left.\mathrm{Mg} \mathrm{ha}^{-1}\right)$ was larger than the average $\mathrm{C}$ in the aboveground biomass for tropical forests in Malaysia (149 $\mathrm{Mg} \mathrm{ha}^{-1}$ ) but smaller than estimates in the Phillipines (406 $\mathrm{Mg} \mathrm{ha}^{-1}$ ) reported by Tara (2012) and Lasco et al. (2006), respectively. The study result indicated that average aboveground $\mathrm{C}$ in the tree plantations was better in eucalyptus species (205.07 $\mathrm{Mg} \mathrm{ha} \mathrm{ha}^{-1}$ and Cupressus lusitanica (180.14 $\mathrm{Mg} \mathrm{ha}^{-1}$ ) as they are relatively older than other tree plantations. The mean belowground $\mathrm{C}$ for the natural forest $\left(72.45 \mathrm{Mg} \mathrm{ha}^{-1}\right)$ was much higher than that tropical forest in Malaysia (27 $\mathrm{Mg} \mathrm{ha}^{-1}$ ) (Tara 2012). The contributions of DTC and LC to the total C pool were minor which might be due to decomposition of dead wood over time leading to loss of $\mathrm{C}$.

The mean SOC storage potential to a depth of $60 \mathrm{~cm}$ in Chato forest was $49.25 \mathrm{Mg} \mathrm{ha}^{-1}$, where natural forest and plantations stored averagely $71.04 \mathrm{Mg} \mathrm{ha}^{-1}$ and $44.90 \mathrm{Mg}$ $\mathrm{ha}^{-1}$, respectively. The average SOC for the natural forest in the present study was a little higher than SOC stock range of 58.3 to $63.9 \mathrm{Mg} \mathrm{ha}^{-1}$ reported by Solomon et al. (2002) for humid tropical forest in southeastern Ethiopia and that of plantations is at par with $44.2 \mathrm{Mg} \mathrm{ha}^{-1}$ reported by Thomas et al. (2015). Mulugeta Lemenih et al. (2005) also found SOC storage of $23.4 \mathrm{Mg} \mathrm{ha}^{-1}$ for Cupressus lusitanica plantation which is lower than our findings $\left(53.16 \mathrm{Mg} \mathrm{ha}^{-1}\right)$. The amount of $\mathrm{C}$ stored in the soil was greatly affected by species richness, age, size and density of forest and the understory cover. In forests with high plant diversity, it is likely that they would have litters with different degrees of chemical resistance; creating the possibility of longer residence of $\mathrm{C}$ through slower decomposition of litters and build up of soil $\mathrm{C}$. As $\mathrm{C}$ is generally a more variable 
parameter, coefficient of variability $(\mathrm{CV})$ was high for most

$\mathrm{C}$ pools investigated within different forest stands (Table 3 ).

Relatively, C stock variation within stand type was highest in DTC pool (71.50\%) and lowest in SOC pool (33.38\%). This implies $\mathrm{C}$ in the vegetation is more variable than $\mathrm{C}$ in the soil.



Fig. 2: Carbon partitioning/mean proportion of $C$ stock in different pools in Chato forest

\subsection{Net carbon sequestration rate}

Plantation forest established in the study site some 31 years back had added nearly $175.93 \mathrm{Gg} \mathrm{C}$ to the forest ecosystem. Our result shows that the average $\mathrm{C}$ sequestration rate for the plantations of varying age was $8.65 \mathrm{Mg} \mathrm{ha}^{-1} \mathrm{yr}^{-1}$; the quantity higher than the average value of $3.98 \mathrm{Mg} \mathrm{ha}^{-1} \mathrm{yr}^{-1}$ for mixed plantation forest in China reported by Yuanqi et al. (2015). Previous research indicated that plantation forests are a cost-effective means of sequestering C (Adams et al. 1999). Among plantations, eucalyptus species and Cupressus lusitanica were relatively matured and thus, stored more $\mathrm{C}$ than other plantations (Table 3). Young forest holds less $\mathrm{C}$, but it is sequestering additional $\mathrm{C}$ over time. An old forest may not be capturing significant quantity of net new $\mathrm{C}$ but can continue to hold large volumes of $\mathrm{C}$ in the form of biomass over long periods of time. In line with this, Lewis et al. (2009) indicated that old natural forests may not be $\mathrm{C}$ neutral but continue to be $\mathrm{C}$ sinks and observed a slow increasing tree $\mathrm{C}$ storage rate of $0.49 \mathrm{Mg} \mathrm{ha}^{-1} \mathrm{yr}^{-1}$ in African tropical old growth forests. Generally, a study by Popo-ola et al. (2012) indicated that planting new forests, rehabilitating degraded forests and enriching existing forests contribute to mitigating climate change as these actions increase the rate and quantity of $\mathrm{C}$ sequestration in biomass.

\subsection{Climate change mitigation and economic potential of the forest}

In the entire forest ecosystem, a total of $6371.30 \mathrm{Gg} \mathrm{C}$ was stored in the vegetation plus soil (Table 4).

Table.4: Total C stock and equivalent carbon-dioxide sink across different forest stands

\begin{tabular}{lcc}
\hline Forest category & Total C stock $(\mathrm{Gg})$ & Equivalent $^{\mathrm{CO}} \mathrm{O}_{2}$ sink $(\mathrm{Gg})$ \\
\hline Eucalyptus spp. & 52.42 & 192.38 \\
Acacia spp. & 0.65 & 2.38 \\
Cupressus lustanica & 121.75 & 446.83 \\
Juniperus procera & 0.64 & 2.35 \\
Gravellia robusta & 0.47 & 1.72 \\
Natural forest & 6195.37 & 22737.00 \\
\hline
\end{tabular}

$* 1 \mathrm{Gg}=1000$ tons 
Here, deforestation of each 1 hectare of natural forest and plantations would cause the loss of about 453.21 and 208.08 $\mathrm{Mg} \mathrm{C}$, respectively. Supposed deforestation of the whole Chato forest would emit $23382.65 \mathrm{Gg} \mathrm{CO}_{2}$ to the atmosphere. Thus, sustainability of the forest has a clear implication to the global climate change. However, owing to protection of existing forests and expansion of plantations in the study area, there is rather a net addition of C to the forest ecosystem. Perez et al. (1997) suggested that the additional $\mathrm{C}$ sequestered from afforestation and reforestation could offset even the $\mathrm{C}$ release from deforestation.

As net gain is the main concern in climate change mitigation strategies, the jungle forests of Amazon cannot be qualified for REDD+ if there is no positive addition of $\mathrm{C}$ to the system. The $\mathrm{C}$ emitted to the atmosphere from industries and other anthropogenic activities need to be offset by removal of the $\mathrm{C}$ by vegetation and artificial means, if any. In our study, we recognized that the undisturbed Chato forest fulfills the key REDD+ strategic areas and would be eligible for the international $\mathrm{C}$ market. By continuing the current afforestation and forest management program, the forest will be a potential emission reduction center. Tree seedling plantations on bare lands around the forest need to be strengthened to add more $\mathrm{C}$ to the system. Community should be empowered to own the forest and protect from potential dangers. Local government authorities need to be transparent and strong enough to protect the forest from potential destruction by private firms and individuals who involve in timber and charcoal production, if any. Generally, organizations working on REDD+ projects need to be transparent enough to ensure sustainability of the Chato forest if they are really concerned with tackling global climate change through afforestation, reforestation and forest management.

\section{CONCLUSION}

Forest type, density, maturity stage and status of protection affect level of biomass accumulation. We understood that the undisturbed and matured natural forest stored more biomass than plantations. Intactness and species diversity of Chato moist evergreen Afromontane forest makes it one of the largest $\mathrm{C}$ reservoirs in the tropics. Carbon allocation was by far larger for the aboveground pool than any other pools. Younger and fast growing plantations have better $\mathrm{C}$ sequestration rate than the old forest and ensures net positive $\mathrm{C}$ additions to the forest ecosystem. Large volume of annually trapped $\mathrm{C}$ by the vast channels of Chato forest makes it the most significant regulator of global climate change. Sustaining the afforestation and forest management programs will possibly ensure the viability of the forest for REDD+ projects. Lastly, more research is required to explore the untapped potential of the forest and give due attention to develop $\mathrm{C}$ models specific to the sacred Afromontane forests.

\section{REFERENCES}

[1] Abel Girma, Teshome Soromessa, Tesfaye Bekele. 2014. Forest carbon stocks in woody plants of mount Zequalla Monastery and its variation along altitudinal gradient: Implication of managing forests for climate change mitigation. Science, Technology and Arts Research Journal 3(2): 132-140.

[2] Adams, D.M., Alig, R.J., McCarl, B.A., Callaway, J.M. and Winnett, S.M. 1999. Minimum cost strategies for sequestering carbon in forests. Land Economics 75: 360-374.

[3] Batjes, N.H. 1996. Total $\mathrm{C}$ and $\mathrm{N}$ in soils of the World. European Journal of Soil Science 47:151-163.

[4] Blake, G.R. and Hartge, K.H. 1986. Bulk Density and Particle Density. In Methods of Soil Analysis, A. Klute (ed.), Part I, Physical and Mineralogical Methods ( $2^{\text {nd }}$ edition), ASA and SSSA Agronomy Monograph, Madison, WI. 9: 363-381.

[5] Brendan, G.M., Heather, K., Sandra, L.B. and David, B.L. 2008. The Wilderness Society of: Green Carbon, the role of natural forests in carbon storage, ANU E Press.

[6] Brown, S. and Lugo, A.E. 1982. The storage and production of organic matter in tropical forests and their role in the global carbon cycle. Biotropica 14: 161-187.

[7] Cairns, M.A., Brown, S., Helmer, E.H. and Baumgardner, G.A. 1997. Root biomass allocation in the world's upland forests. Oecologia 111: 1-11.

[8] Chave, J., Andalo, C., Brown, S., Cairns, M.A., Chambers, J.Q., and Eamus, D. 2005. Tree allometry and improved estimation of carbon stocks. Oecologia, 145: 87-99.

[9] Craig, L., Amanda, S., David, D. and Elliot, D. 2010. Soil carbon and climate change, PIRSA Discussion Paper, Australia.

[10]CSEMF-Center for Standardization and Environment Ministry of Forestry. 2011. Measurement and calculation of carbon stocks-field measurement for 
estimating forest carbon stocks (ground based forest carbon accounting), Indonesia, 16p.

[11] EFAP-Ethiopian Forestry Action Program. 1994. The challenge for development. Final Report, Vol. 2, Ministry of Natural Resources Development and Environmental Protection, Ethiopian Forestry Action Program Secretariat, Addis Ababa.

[12] Ervan, R., Fatmi, N. and Louis, V. 2013. Generic allometric models including height best estimate forest biomass and carbon stocks in Indonesia. Forest Ecology and Management 307: 219-225.

[13]Hairiah, K., Dewi, S., Agus, F., Velarde, S., Ekadinata, A., Rahayu, S. and Van Noordwijk, M. 2011. Measuring carbon stocks across land use systems: A Manual. Bogor, Indonesia. World Agroforestry Centre (ICRAF), SEA Regional Office, 154 pages.

[14] IPCC. 2006. IPCC Guidelines for National Greenhouse Gas Inventories, Prepared by the National Greenhouse Gas Inventories Programme, Eggleston H.S., Buendia L., Miwa K., Ngara T. and Tanabe K. (eds). Published: IGES, Japan.

[15]Lal, R. 2004. Soil carbon sequestration impacts on global change and food security. Science 304: 16231627.

[16]Lal, R. 2005. Forest soils and carbon sequestration. Forest Ecology and Management 220 (1-3): 242-258.

[17]Lasco, R.D., MacDicken, K.G., Pulhin, F.B., Guillermo, I.Q., Sales, R.F. and Cruz, R.V.O. 2006. Carbon stocks assessment of a selectively logged dipterocarp forest and wood processing mill in the Philippines. Journal of Tropical Forest Science 18: 212-221.

[18] Lewis, S.L., Lopez-Gonzalez, G., Sonke, B. et al. 2009. Increasing carbon storage in intact African tropical forests. Nature 477: 1003-1006.

[19] Mulugeta Lemenih, Bekele Lemma, Demel Teketay. 2005. Changes in soil carbon and total nitrogen following reforestation of previously cultivated land in the highlands of Ethiopia. Ethiopian Journal of Science 28(2): 99-108.

[20] Murdiyarso, D. and Wasrin, U.R. 1995. Estimating land use change and carbon release from tropical forests conversion using remote sensing technique. Journal of Biogeography 22: 715-721.

[21]Payton, I. and Weaver, S. 2011. Fiji national forest carbon stock assessment. SPC/GIZ regional programme coping with climate change in the Pacific Island Region and the Fiji Forestry Department.

[22]Pearson, T., Walker, S. and Brown, S. 2005. Sourcebook for land-use, land-use change and forestry projects: Win rock International and the Bio-carbon fund of the World Bank. Arlington, USA, pp. 19-35.

[23] Perez, G.J., Oliver, C.D. and Lippke, B. 1997. "How forests can help reduce carbon dioxide emissions to the atmosphere," U.S. Congress, House Resources, Forests and Forest Health, Hearing on H. Con. Res 151, 105th Cong., 1st session, Serial No. 105-61 (Washington: GPO, 1998), pp. 46-68.

[24] Popo-ola, F.S., Aiyeloja, A.A. and Adedeji, G.A. 2012. Sustaining carbon sink potentials in tropical forest. Journal of Agriculture and Social Research 12 (1): 64-73.

[25] Rai, S.N. 1981. Productivity of tropical rain forests of Karnataka. Ph.D. Thesis, University of Bombay, Bombay, India.

[26] Ratul, B., Saroj, K.B. and Krishna, U. 2009. Distribution pattern of aboveground biomass in natural and plantation forests of humid tropics in northeast India. Tropical Ecology 50(2): 295-304.

[27] Schmitt, G.A., Ruedy, R.A., Miller, R.L., Lacis, A.A. 2010. Attribution of the present day total greenhouse effect. Journal of Geographical Research 115, D20106, doi: 10.1029/2010JD014287.

[28] Solomon, D., Lehman, J., Zech, W. 2002. Land use effects on soil organic matter properties of chromic luvisols in semi-arid northern Tanzania: Carbon, nitrogen, lignin and carbohydrates. Agriculture, Ecosystems and Environment 78: 203-213.

[29] Tara, L.D. 2012. Thorough quantification of tropical forest carbon stocks in Malaysia. University of California, Berkeley Environmental Sciences, pp. $1-18$.

[30]Thomas, G., Muhammed, D., Yakov, K. 2015. Losses of soil carbon by converting tropical forest to plantations: erosion and decomposition by $\delta{ }^{13} \mathrm{C}$. Global Change Biology 21: 3548-3560.

[31] Tibebu Yelemfrhat, Teshome Soromessa, Eyale Bayable. 2014. Forest carbon stocks in lowland area of Simien Mountains National Park: Implication for climate change mitigation. Science, Technology and Arts Research Journal 3(3): 29-36.

[32] Walkley, A. and Black, I.A. 1934. An examination of the Degtjareff method for determining organic carbon in soils: Effect of variations in digestion conditions 
and of inorganic soil constituents. Soil Science 63: 251-263.

[33] Wondrade, N., Dick, O.B., Tveite, H. 2015. Estimating above Ground Biomass and Carbon Stock in the Lake Hawassa Watershed, Ethiopia by Integrating Remote Sensing and Allometric Equations. Forest Res 4:151. doi:10.4172/2168-9776.1000151.

[34] Yitebitu Moges, Zewdu Eshetu, Sisay Nune. 2010. Ethiopian forest resources: current status and future management options: In view of access to carbon finances. Literature review prepared for the Ethiopian climate research and networking and United Nations Development Programme (UNDP), Addis Ababa, Ethiopia.

[35] Yuanqi, C., Zhanfeng, L., Xingquan, R., Xiaoling, W., Chenfei, L., Yongbiao, L., Lixia, Z., Xi-an, C. and Shenglei, F. 2015. Carbon storage and allocation pattern in plant biomass among different forest plantation stands in Guangdong, China. Forests 6: 794-808.

[36]Zerihun Getu, Tadesse Woldemariam, Winston Adams. 2012. Forest carbon stock assessment manual for REDD+ in Ethiopia. 